\title{
Estimating chemical footprint: Contamination with mercury and its compounds
}

\author{
Tarasova, Natalia; Makarova, Anna; Fantke, Peter; Shlyakhov, Pavel
}

Published in:

Pure and Applied Chemistry

Link to article, DOI:

10.1515/pac-2017-1102

Publication date:

2018

Document Version

Publisher's PDF, also known as Version of record

Link back to DTU Orbit

Citation $(A P A)$ :

Tarasova, N., Makarova, A., Fantke, P., \& Shlyakhov, P. (2018). Estimating chemical footprint: Contamination with mercury and its compounds. Pure and Applied Chemistry, 90(5), 857-868. https://doi.org/10.1515/pac-20171102

\section{General rights}

Copyright and moral rights for the publications made accessible in the public portal are retained by the authors and/or other copyright owners and it is a condition of accessing publications that users recognise and abide by the legal requirements associated with these rights.

- Users may download and print one copy of any publication from the public portal for the purpose of private study or research.

- You may not further distribute the material or use it for any profit-making activity or commercial gain

- You may freely distribute the URL identifying the publication in the public portal 


\title{
Natalia Tarasova, Anna Makarova*, Peter Fantke and Pavel Shlyakhov Estimating chemical footprint: contamination with mercury and its compounds
}

https://doi.org/10.1515/pac-2017-1102

\begin{abstract}
Chemical pollution is a problem of global importance. However, there are currently no agreed approaches for integrated environmental impact assessment (EIA) of chemical effects at global scale. We present a new systems-based approach to EIA of chemicals. Our methodology considers propagation of chemical pollutants in the environment, in conjunction with the approach followed in the Russian regulatory system. To estimate chemical footprints related to environmental contamination by potentially toxic substances, measured environmental concentrations were combined with results from the UNEP-SETAC scientific consensus model USEtox, which is recommended for and widely applied in life cycle impact assessment. Our approach was tested using the example of mercury, which has been shown to be a hazardous pollutant at regional and global scales. Results show that the main contribution to the overall chemical footprint of mercury and its compounds is related to releases into aqueous bodies from human activities. Estimations of Maximum Available Concentration overrun show that calculated and experimental data agree to a good extent, particularly for mercury contamination in freshwater bodies. Discrepancies between calculated and actual data are mainly due to extrapolated data used for model validation, averaged data applied to entire Russian Federation districts, the omission of industrial soil as a separate model compartment, and not accounting for cumulative damage from emissions in previous years. These aspects will inform future efforts to refine the methodology. The results of this study were presented to the Ministry of the Natural Resources and Environment of the Russian Federation. It is planned to use these results as one basis for prioritizing action on sources of environmental mercury contamination and as a benchmark for minimizing such impacts.
\end{abstract}

Keywords: chemical footprint; environmental impact assessment (EIA); MAM-17; mercury; planetary boundaries; systems approach.

Article note: A collection of invited papers based on presentations at $8^{\text {th }}$ International IUPAC Symposium on Macro- and Supramolecular Architectures and Materials: Multifunctional Materials and Structures (MAM-17) held in Sochi, Russia, 6-10 June 2017.

\footnotetext{
*Corresponding author: Anna Makarova, Mendeleyev University of Chemical Technology of Russia, UNESCO Chair Green Chemistry for Sustainable Development, Miusskaya Square, 9, building 3, Moscow 125047, Russian Federation, Tel.: +79104592664 , e-mail: annmakarova@mail.ru

Natalia Tarasova: Mendeleev University of Chemical Technology of Russia, Institute of Chemistry and the Problems of Sustainable Development, Moscow, Russian Federation

Peter Fantke: Technical University of Denmark, Division for Quantitative Sustainability Assessment, Lyngby, Denmark Pavel Shlyakhov: Mendeleyev University of Chemical Technology of Russia, UNESCO Chair Green Chemistry for Sustainable Development, Miusskaya Square, 9, building 3, Moscow 125047, Russian Federation; and Lomonosov Moscow State University, Faculty of Computational Mathematics and Cybernetics, Moscow, Russian Federation
} 


\section{Introduction}

The development of contemporary societies has been accompanied by increasing negative impacts on the environment and human health [1]. Estimating the limits of these impacts is one of the systemic technological problems that researchers from diverse disciplines jointly aim to address [2, 3]. In 2009, the "planetary boundaries" concept was proposed Rockström et al. [3, 4]. Subsequently, Steffen et al. [5] made some modifications to this concept; in particular, in addition to the boundaries themselves, areas with moderate and extraordinary risk of negative impact beyond the carrying capacities (i.e. boundaries) of our planet were identified. One of the nine planetary boundaries suggested by Rockström et al. [3] is directly related to the impact of anthropogenic chemical releases into the environment. However, specific numerical parameters and tools have not been fully elaborated for a systems-based approach to integrated assessment for quantifying the environmental impacts of the various chemicals currently in use. Nevertheless, a few studies have investigated approaches for estimating this boundary [6]. In particular, it has been suggested that planetary boundaries be estimated from pressures associated with the release of toxic chemicals using the ecological footprint concept [7], an emerging concept applied in first estimates of environmental impacts [8]. This concept reflects the consumption of biosphere resources by human societies [9]. It is quantified in "global green hectares", i.e. areas of biologically productive territories and water needed for production of resources used by humans, and for assimilation and conversion of resulting wastes (both household and industrial).

Currently, a number of researchers are engaged in developing methods for estimating chemical footprints (ChF) [10]. Panko and Hitchcock [11] suggest that ChF should incorporate the risks of adverse environmental impacts by a chemical throughout its entire life cycle. The Clean Production Action company [12] suggests determining $\mathrm{ChF}$ as the total amount of hazardous chemicals embedded in a company product and/or the chemicals used by a company in its production activities, which would also inform efforts to phase-out harmful chemicals and replace them with fundamentally more sustainable alternatives [13]. In practice, other researchers determine $\mathrm{ChF}$ as the volume of pure water theoretically required for the dilution of chemicals that are released to aquatic environments, down to concentrations that are safe for freshwater ecosystems [14]; that definition was used as the basis for the present study, and modified taking into consideration the specific characteristics of mercury contamination of the environment.

Mercury is a well-known hazardous chemical and studies estimating its ecological impacts are ongoing (e.g. Liang et al. [15, 16]). Emissions and dumping of mercury and its compounds create considerable risks for the environment and for human health. The necessity of ensuring protection of the environment and human health from exposure to mercury has been well described [17] and the dangers of mercury contamination have received worldwide recognition, resulting in the Minamata Convention on Mercury [18].

It should be noted that the extremely high saturation vapor pressure of mercury is mainly responsible for the easy transfer of elementary mercury to the gas phase and hence plays an important role in atmospheric migration of mercury over long distances [19]. Additionally, water-soluble forms of mercury have enhanced sorptivity and can hence accumulate in biota. Therefore, starting from the $\mathrm{ChF}$ approach proposed by Bjørn et al. [14] for heavy metals, and adopting the standpoint of systems analysis and computer-aided integrated environmental impact assessment (EIA) methods, we suggest for the first time that not only the hydrosphere but also the atmosphere and soil (as part of the lithosphere) should be taken into account in ChF calculations. Based on these aspects, it is the aim of the present study to quantify a mercury chemical footprint (comprising the chemical footprint of mercury and its compounds), $\mathrm{ChF}^{\mathrm{Hg}}$, with a focus on the territory of the Russian Federation, adopting the concept of ecological footprint as a quantitative approach that describes the ecological space required to dilute chemical pollution resulting from social and economic activities of humans to levels below predefined, desirable limits.

\section{Materials and methods}

Mercury enters the environment and its subsystems through various pathways - via emissions to atmospheric air of populated areas, via waste discharged into water bodies, and via disposal of industrial and con- 
sumer waste in soil. Accordingly, the present study suggests a systems analysis methodology for estimating $\mathrm{ChF}^{\mathrm{Hg}}$ as a maximum of the three possible relative (specific) concentrations of mercury in the atmosphere, hydrosphere, and soil as part of the lithosphere:

$$
\operatorname{ChF}^{\mathrm{Hg}}=\max \left\{\frac{\mathrm{V}_{\mathrm{a}}^{\mathrm{Hg}}}{\mathrm{V}_{\mathrm{a}}^{\mathrm{sy}}} ; \frac{\mathrm{V}_{\mathrm{w}}^{\mathrm{Hg}}}{\mathrm{V}_{\mathrm{w}}^{\mathrm{sys}}} ; \frac{\mathrm{M}_{\mathrm{s}}^{\mathrm{Hg}}}{\mathrm{M}_{\mathrm{s}}^{\mathrm{sys}}}\right\}
$$

where $\mathrm{V}_{\mathrm{a}}^{\mathrm{Hg}}$ is the volume of air required to dilute mercury and its compounds discharged into the atmosphere to safe (i.e. below set, acceptable thresholds) concentrations; $V_{a}^{\text {sys }}$ is the volume of air in the system; $V_{w}^{H g}$ is the volume of water required to dilute mercury and its compounds discharged into surface freshwater bodies of the hydrosphere to safe concentrations; $V_{w}^{\text {sys }}$ is defined as the volume of freshwater in the system; $\mathrm{M}_{\mathrm{s}}^{\mathrm{Hg}}$ is the mass of soil required for dilution of mercury and its compounds released to soil to safe concentrations; and $\mathrm{M}_{\mathrm{s}}^{\mathrm{Hg}}$ is defined as available bulk soil mass. The values of $\mathrm{V}_{\mathrm{a}}^{\mathrm{sys}}, \mathrm{V}_{\mathrm{w}}^{\text {sys }}$, and $\mathrm{M}_{\mathrm{s}}^{\text {sys }}$ used in Eq. 1 were calculated as follows:

$$
\mathrm{V}_{\mathrm{a}}^{\text {sys }}=\mathrm{A}_{\text {sys }} \times \mathrm{h}_{\mathrm{a}}
$$

where $h_{a}$ is the atmospheric mixing height relevant for mercury in meters (1000 m was used as a default value); and $\mathrm{A}_{\mathrm{sys}}$ is the system area of the Russian Federation (RF) district $\left(\mathrm{m}^{2}\right)$;

$$
\mathrm{V}_{\mathrm{w}}^{\text {sys }}=\mathrm{V}_{\text {lake }}^{\text {sys }}+\mathrm{V}_{\text {res }}^{\text {sys }}+\mathrm{V}_{\text {riv }}^{\text {sys }}
$$

where $V_{\text {lake }}^{\text {sys }}$ is the total volume of water in lakes $\left(\mathrm{m}^{3}\right)$; $V_{\text {res }}^{\text {sys }}$ is the total volume of water in dammed freshwater bodies $\left(\mathrm{m}^{3}\right)$; and $V_{\text {riv }}^{\text {sys }}$ is the total volume of water in rivers $\left(\mathrm{m}^{3}\right)$ within the territory considered. The values of $\mathrm{V}_{\text {lake }}^{\text {sys }}, \mathrm{V}_{\text {res }}^{\text {sys }}$, and $\mathrm{V}_{\text {riv }}^{\text {sys }}$ were calculated using the algorithm described by Helmes et al. [20]

$$
\mathrm{M}_{\mathrm{s}}^{\mathrm{sys}}=\mathrm{A}_{\mathrm{s}} \times \mathrm{h}_{\mathrm{s}} \times \rho
$$

where $h_{s}$ is the average soil depth in $\mathrm{cm}\left(10 \mathrm{~cm}\right.$ was used as default value); $\mathrm{A}_{\mathrm{s}}$ is the soil area of the RF district $\left(\mathrm{m}^{2}\right)$; and $\rho$ is the bulk soil density $\left(\mathrm{g} / \mathrm{cm}^{3}\right)$.

We calculate $\mathrm{V}_{\mathrm{a}}^{\mathrm{Hg}}$ using the following equation:

$$
\mathrm{V}_{\mathrm{a}}^{\mathrm{Hg}}=\mathrm{m}_{\mathrm{a}}^{\mathrm{Hg}} /\left(\operatorname{Lim}_{\mathrm{a}}^{\mathrm{Hg}} \times 10^{-6}\right)
$$

where $\mathrm{m}_{\mathrm{a}}^{\mathrm{Hg}}$ is the mass of mercury and its compounds (with respect to mercury) present in the atmosphere above the area in question $(\mathrm{kg})$; $\operatorname{Lim}_{\mathrm{a}}^{\mathrm{Hg}}$ is the maximum allowable concentration (MAC) of mercury and its compounds in the air of populated areas $\left(\mathrm{mg} / \mathrm{m}^{3}\right)$; and $10^{-6}$ is a conversion factor from $\mathrm{mg}$ to $\mathrm{kg}$. Analogously, the value of $\mathrm{V}_{\mathrm{w}}^{\mathrm{Hg}}$ was calculated using the following equation:

$$
\mathrm{V}_{\mathrm{w}}^{\mathrm{Hg}}=\mathrm{m}_{\mathrm{w}}^{\mathrm{Hg}} /\left(\operatorname{Lim}_{\mathrm{w}}^{\mathrm{Hg}} \times 10^{-3}\right)
$$

where $\mathrm{m}_{\mathrm{w}}^{\mathrm{Hg}}$ is the mass of mercury and its compounds contained in water bodies within the area being studied (without consideration of cumulative damage in previous years), (kg); and $\operatorname{Lim}_{\mathrm{w}}^{\mathrm{Hg}}$ is the MAC of mercury and its compounds in fishery waters $(\mathrm{mg} / \mathrm{l})$; and $10^{-3}$ is a conversion factor from $\mathrm{mg}$ to $\mathrm{kg}$ and $\mathrm{l}$ to $\mathrm{m}^{3}$. Finally, the value of $\mathrm{M}_{\mathrm{s}}^{\mathrm{Hg}}$ was calculated using the following equation:

$$
\mathrm{M}_{\mathrm{s}}^{\mathrm{Hg}}=\mathrm{m}_{\mathrm{s}}^{\mathrm{Hg}} /\left(\operatorname{Lim}_{\mathrm{s}}^{\mathrm{Hg}} \times 10^{-6}\right)
$$

where $\mathrm{m}_{\mathrm{s}}^{\mathrm{Hg}}$ is the total mass of mercury contained in soil $(\mathrm{kg})$ in the area being studied (without considering damage accumulated in previous years); and $\operatorname{Lim}_{\mathrm{s}}^{\mathrm{Hg}}$ is the mass-based MAC of mercury in soil (mg/kg); and $10^{-6}$ is a conversion factor from $\mathrm{mg}$ to $\mathrm{kg}$.

The following officially established hygienic regulations for mercury and its compounds were used for values of $\operatorname{Lim}_{\mathrm{a}}^{\mathrm{Hg}}, \operatorname{Lim}_{\mathrm{w}}^{\mathrm{Hg}}$, and $\operatorname{Lim}_{\mathrm{s}}^{\mathrm{Hg}}$ in Eqs. $5-7$ : in atmospheric air, daily average $\mathrm{MAC}=0.0003 \mathrm{mg} / \mathrm{m}^{3}$ 
[21]; in fisheries (water within water bodies of commercial fishing importance, including marine water), $\mathrm{MAC}=0.00001 \mathrm{mg} / 1$ [22]; and in soil, $\mathrm{MAC}=2.1 \mathrm{mg} / \mathrm{kg}$ [23].

The amount of mercury in subsystems of the environment $\left(\mathrm{m}_{\mathrm{a}}^{\mathrm{Hg}}, \mathrm{m}_{\mathrm{w}}^{\mathrm{Hg}}\right.$, and $\left.\mathrm{m}_{\mathrm{s}}^{\mathrm{Hg}}\right)$ in Eqs. 5-7 was calculated using the principles and methodology of product life cycle assessment (LCA), according to ISO 14040:2006 [24], whereby the processes leading to mercury fate and distribution in the environment can be represented by a simplified block diagram (Fig. 1).

According to the pathways presented in Fig. 1, change of mercury content in environmental compartment $\mathrm{j}$ (atmosphere, hydrosphere, or soil as part of the lithosphere) can be estimated using the following equation:

$$
\frac{\mathrm{dm}_{\mathrm{j}}(\mathrm{t})}{\mathrm{dt}}=\mathrm{s}_{\mathrm{j}}-\sum_{\mathrm{n}=1}^{\mathrm{N}-1} \mathrm{k}_{\mathrm{j} \rightarrow \mathrm{n}}^{\text {migr }} \times \mathrm{m}_{\mathrm{j}}+\sum_{\mathrm{n}=1}^{\mathrm{N}-1} \mathrm{k}_{\mathrm{n} \rightarrow \mathrm{j}}^{\text {migr }} \times \mathrm{m}_{\mathrm{n}}-\mathrm{k}_{\mathrm{j}}^{\text {transb }} \times \mathrm{m}_{\mathrm{j}}
$$

It should be noted that one goal of this study was to estimate the maximum total amount of mercury, so degradation was set to zero, such that $\left(\mathrm{dm}_{\mathrm{j}}^{\mathrm{deg}}(\mathrm{t}) / \mathrm{dt}\right)=0$. With that, Eq. 8 can be rewritten as a function of rate constants:

$$
0=s_{j}-\sum_{n=1}^{N-1} k_{j \rightarrow n}^{\text {migr }} \times m_{j}+\sum_{n=1}^{N-1} k_{n \rightarrow j}^{\text {migr }} \times m_{n}-k_{j}^{\text {transb }} \times m_{j}
$$

In estimating $\mathrm{ChF}^{\mathrm{Hg}}$, the boundaries of the system being studied are the predefined limits of changes in the environmental compartments or subsystems, i.e. atmosphere, hydrosphere, and soil. The boundaries of the systems being studied for estimating the impacts of mercury and the determination of $\mathrm{ChF}^{\mathrm{Hg}}$ are set as the $\mathrm{RF}$ districts.

The following relationship is applied for environmental subsystems and geographic regions in question, provided that processes of mercury circulation in the environment (migration from one environment subsystem to another; transfer to areas beyond the boundaries of the system being studied) are in equilibrium, and that ingress of the compound into the system is mainly due to the existence of fixed technological sources of effluents, emissions, and formation of mercury-containing wastes [25]:

$$
\overrightarrow{\mathrm{m}}=-\mathbf{K}^{-1} \overrightarrow{\mathrm{S}}=\mathbf{F F} \overrightarrow{\mathrm{s}}
$$

where $\overrightarrow{\mathrm{m}}$ is a column-vector describing the mass content of a chemical $(\mathrm{kg})$ in environmental subsystems under steady-state conditions; $\mathbf{K}$ is a square matrix containing constant rate coefficients (day $\left.{ }^{-1}\right)$ describing the variation in the mass content of chemicals in the environment, and $\vec{s}$ is a column-vector of continuous emissions ( $\mathrm{kg} /$ day) representing the capacity of the sources of mercury ingress to environmental subsystems.

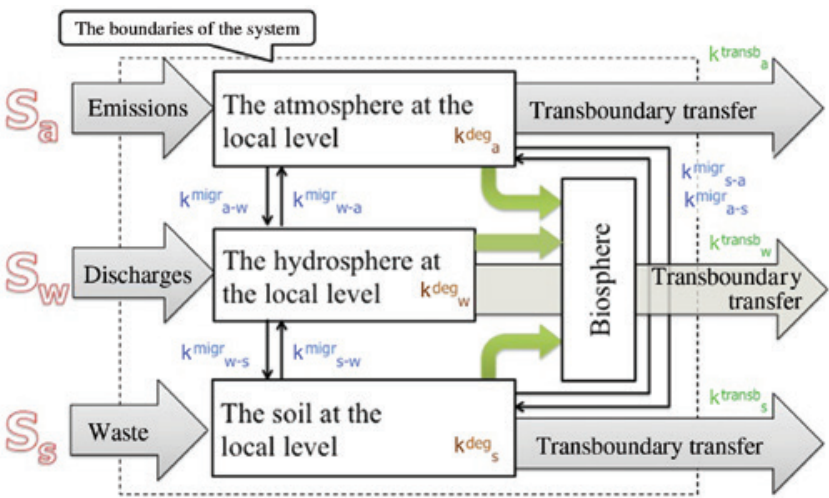

Fig. 1: The transformation of chemicals in the environment. $S_{a}, S_{w}$, and $S_{s}$ are sources of chemical ingress to the atmosphere, hydrosphere, and soil (as part of the lithosphere), respectively. The following represent rate constants: $k^{\text {migr }}{ }_{j-n}$, the migration of chemicals from environmental component $j$ to $N ; k^{\text {transb }}$, transfer of chemicals from environmental component $j$ being studied to beyond the system boundaries; $k_{j}^{\text {deg }}$, degradation of chemicals being studied in environmental component $j$. 
The main diagonal elements of $\mathbf{K}$ reflect the total rates of chemical removal from an environment subsystem (including migration to other subsystems and transfer to areas beyond the system boundaries), while the other elements in this matrix represent individual bulk transfer processes of chemicals from one subsystem to another. Finally, FF is the matrix of fate factors (day), whose elements account for multimedia migration, conversion, and degradation of chemicals in the environment at steady state. The values of the elements of $\mathbf{F F}$ depend on the physicochemical properties of chemicals, and are obtained by inversion of matrix $\mathbf{K}$ of rate coefficients.

Mathematical models describing the conversion and propagation of chemicals in various environmental subsystems and enabling calculation of the elements of FF have been developed since 1978 [26]. Examples of such mathematical fate and exposure models include Impact 2002 [27], USEtox [28], and others. A number of researchers have estimated $\mathrm{ChF}$ values using the UNEP-SETAC scientific consensus model USEtox, which is recommended for and widely applied in life cycle impact assessment and other comparative assessments [29], and which not only calculates the propagation and conversion of chemicals in the environment but also estimates their toxicological impacts on freshwater ecosystems and human health. In the present work, USEtox was used to calculate the elements of the matrix FF in estimating ChF for mercury adapted for the RF region.

\section{Data acquisition and processing for calculating mercury footprints}

$\mathrm{ChF}^{\mathrm{Hg}}$ was estimated separately for the eight districts of the Russian Federation (RF districts), namely for the North Caucasian, Central, Far Eastern, Siberian, Urals, North-Western, Privolzhsky, and Southern districts and for 78 regions of the Russian Federation. To calculate the elements of the FF matrix in USEtox, arrays of yearly average data from RF districts were collected and are summarized in Tables 1 and 2; wind speeds and soil densities were taken from respective maps for the year 2014.

To calculate mercury releases from anthropogenic sources into environment subsystems (i.e. atmosphere, hydrosphere, and soil) of the studied RF districts and regions, we used data provided by various industrial plants as part of the national inventory of mercury emissions in Russia, conducted in 2012. Emissions of mercury and its compounds to the environment were estimated for the following sources: during recovery and use of coal, oil, and natural gas; from extraction and use of metals in industrial processes; and from mercury-containing industrial and household equipment.

It should be noted that industrial plants provided data for the mercury emission inventory on a voluntary basis, so required data were partially or entirely missing for a number of plants within regions considered. Where real data on mercury emissions, discharges, and mercury-containing waste disposal were unavailable, we used expert estimates and extrapolation methods to acquire additional data. For example, an integrated assessment of the emissions of mercury and its compounds during zinc production has shown that mercury enters the environment during enrichment of zinc ore to concentrate, and in the production of primary metal

Table 1: Source data for calculation of elements of the [FF] matrix by RF District [34].

\begin{tabular}{|c|c|c|c|c|c|c|c|}
\hline RF districts & $\begin{array}{l}\text { Area land, } \\
\text { thou. } \mathbf{k m}^{2}\end{array}$ & $\begin{array}{r}\text { Average tem- } \\
\text { perature, }{ }^{\circ} \mathrm{C}\end{array}$ & $\begin{array}{r}\text { Wind } \\
\text { speed, } m / s\end{array}$ & $\begin{array}{l}\text { Rain rate, } \\
\mathrm{mm} / \text { year }\end{array}$ & $\begin{array}{r}\text { Soil specific } \\
\text { density, } \mathrm{g} / \mathrm{cm}^{3}\end{array}$ & $\begin{array}{r}\text { River runoff, } \\
\mathrm{km}^{3} / \text { year }\end{array}$ & $\begin{array}{l}\text { Water resour- } \\
\text { ces, } \mathrm{km}^{3} / \text { year }\end{array}$ \\
\hline North Caucasian & 170 & 10.17 & 3 & 547 & 1.2 & 28.0 & 61.4 \\
\hline Central & 650 & 6.98 & 4 & 607 & 1.4 & 126 & 328.2 \\
\hline Far Eastern & 6169 & 6.26 & 3 & 417 & 1.3 & 1848.1 & 2459.7 \\
\hline Siberian & 5145 & -2.51 & 3 & 445 & 1.3 & 1975.7 & 1321.1 \\
\hline Urals & 1819 & -1.64 & 4 & 468 & 1.4 & 597.3 & 1206.1 \\
\hline North-Western & 1687 & 2.38 & 4 & 558 & 1.5 & 607.4 & 867.7 \\
\hline Privolzhsky & 1037 & 4.9 & 4 & 527 & 1.3 & 271.3 & 1490.9 \\
\hline Southern & 421 & 11.38 & 4 & 473 & 1.2 & 288.9 & 560.6 \\
\hline
\end{tabular}


Table 2: Source data on distribution of land reserves in RF Districts by land categories [34].

\begin{tabular}{|c|c|c|c|c|c|c|c|}
\hline \multirow[t]{3}{*}{ RF districts } & \multirow{3}{*}{$\begin{array}{r}\text { Water fund } \\
\text { lands }\end{array}$} & \multirow{3}{*}{$\begin{array}{r}\text { Agricultural } \\
\text { lands }\end{array}$} & \multicolumn{5}{|c|}{ Areas, $\mathrm{km}^{2}$ (fraction) } \\
\hline & & & \multicolumn{3}{|c|}{ Natural soils } & \multicolumn{2}{|r|}{ Other soils } \\
\hline & & & $\begin{array}{r}\text { Land of specially } \\
\text { protected } \\
\text { natural areas }\end{array}$ & $\begin{array}{r}\text { Forestry } \\
\text { lands }\end{array}$ & $\begin{array}{r}\text { Reserve } \\
\text { lands }\end{array}$ & $\begin{array}{l}\text { Industrial } \\
\text { lands etc. }\end{array}$ & $\begin{array}{l}\text { Lands of inha- } \\
\text { bited localities }\end{array}$ \\
\hline North & 1070 & 135702 & 2770 & 17416 & 4633 & 1813 & 7035 \\
\hline Caucasian & $(0.01)$ & $(0.8)$ & $(0.02)$ & $(0.1)$ & $(0.03)$ & $(0.01)$ & $(0.04)$ \\
\hline Central & $\begin{array}{r}7961 \\
(0.01)\end{array}$ & $\begin{array}{r}351749 \\
(0.54)\end{array}$ & $\begin{array}{r}7025 \\
(0.01)\end{array}$ & $\begin{array}{r}209139 \\
(0.32)\end{array}$ & $\begin{array}{r}12315 \\
(0.02)\end{array}$ & $\begin{array}{r}12763 \\
(0.02)\end{array}$ & $\begin{array}{r}49253 \\
(0.07)\end{array}$ \\
\hline Far Eastern & $\begin{array}{r}38628 \\
(0.01)\end{array}$ & $\begin{array}{r}656484 \\
(0.11)\end{array}$ & $\begin{array}{r}181504 \\
(0.03)\end{array}$ & $\begin{array}{r}4947640 \\
(0.8)\end{array}$ & $\begin{array}{r}312690 \\
(0.05)\end{array}$ & $\begin{array}{l}17193 \\
(0.003)\end{array}$ & $\begin{array}{l}15190 \\
(0.001)\end{array}$ \\
\hline Siberian & $\begin{array}{r}65146 \\
(0.01)\end{array}$ & $\begin{array}{r}967001 \\
(0.19)\end{array}$ & $\begin{array}{r}166078 \\
(0.03)\end{array}$ & $\begin{array}{r}3505402 \\
(0.68)\end{array}$ & $\begin{array}{r}382063 \\
(0.07)\end{array}$ & $\begin{array}{r}32054 \\
(0.01)\end{array}$ & $\begin{array}{r}27209 \\
(0.01)\end{array}$ \\
\hline Urals & $\begin{array}{r}89512 \\
(0.05)\end{array}$ & $\begin{array}{r}494889 \\
(0.27)\end{array}$ & $\begin{array}{r}25768 \\
(0.01)\end{array}$ & $\begin{array}{r}1086656 \\
(0.6)\end{array}$ & $\begin{array}{r}82189 \\
(0.05)\end{array}$ & $\begin{array}{r}13069 \\
(0.01)\end{array}$ & $\begin{array}{r}26414 \\
(0.01)\end{array}$ \\
\hline $\begin{array}{l}\text { North- } \\
\text { Western }\end{array}$ & $\begin{array}{r}46678 \\
(0.03)\end{array}$ & $\begin{array}{r}341379 \\
(0.2)\end{array}$ & $\begin{array}{r}66691 \\
(0.04)\end{array}$ & $\begin{array}{r}1069189 \\
(0.63)\end{array}$ & $\begin{array}{r}80301 \\
(0.05)\end{array}$ & $\begin{array}{r}66208 \\
(0.04)\end{array}$ & $\begin{array}{r}16526 \\
(0.01)\end{array}$ \\
\hline Privolzhsky & $\begin{array}{r}17038 \\
(0.02)\end{array}$ & $\begin{array}{r}576238 \\
(0.56)\end{array}$ & $\begin{array}{r}12134 \\
(0.01)\end{array}$ & $\begin{array}{r}362801 \\
(0.35)\end{array}$ & $\begin{array}{r}12630 \\
(0.01)\end{array}$ & $\begin{array}{r}13260 \\
(0.01)\end{array}$ & $\begin{array}{r}42874 \\
(0.04)\end{array}$ \\
\hline Southern & $\begin{array}{r}14318 \\
(0.03)\end{array}$ & $\begin{array}{r}331884 \\
(0.79)\end{array}$ & $\begin{array}{r}7782 \\
(0.02)\end{array}$ & $\begin{array}{r}27236 \\
(0.06)\end{array}$ & $\begin{array}{r}8419 \\
(0.02)\end{array}$ & $\begin{array}{r}15395 \\
(0.04)\end{array}$ & $\begin{array}{r}15842 \\
(0.04)\end{array}$ \\
\hline
\end{tabular}

Table 3: Mercury ingress rate $s$ (kg/year) into various environment subsystems by RF district.

\begin{tabular}{lrrrrrrrr}
\hline Mercury ingress rate & \multicolumn{1}{c}{} & & & RF district \\
\cline { 2 - 9 } & North Caucasian & Central & Far Eastern & Siberian & Urals & North-Western & Privolzhsky & Southern \\
\hline Atmosphere $\left(\mathrm{s}_{\mathrm{a}}\right)$ & 3641 & 4746 & 8511 & 14774 & 9373 & 1458 & 11783 & 1575 \\
Surface freshwater $\left(\mathrm{s}_{\mathrm{w}}\right)$ & 639 & 82 & 3893 & 5620 & 1956 & 75 & 1495 & 144 \\
Natural and other soil $\left(\mathrm{s}_{\mathrm{s}}\right)$ & 14215 & 38879 & 128135 & 278420 & 90506 & 9374 & 101859 & 5827 \\
\hline
\end{tabular}

from zinc concentrate (e.g. [30]). Data on the production, export, and import of primary metals and concentrates were provided during inventory analysis [31].

For mercury emissions during concentrate enrichment, there is insufficient information on ore amounts at particular mines, and available information is often provided by ore treatment plants rather than by mining companies, thereby introducing errors in determining mercury emissions into the environment. The calculation of mercury emissions to the environment during zinc extraction from concentrate takes into consideration that the majority of zinc plants comprise smelting units incorporating wet gas-cleaning and a sulfuric acid production unit, which predetermines a certain ratio of mercury in plant emissions, discharges, and wastes $-10 \%$ of mercury originally present in the concentrates is emitted to air, $2 \%$ to water bodies, $42 \%$ is found in by-products, primarily in sulfuric acid, and $46 \%$ goes into dumps and wastes [32]. The content of mercury in zinc concentrate was known only at one plant (Chelyabinsk Zinc Plant), and this value was taken as a proxy for all other plants. The results for mercury releases into various environment subsystems from various types of industrial plants were generalized by RF district and are shown in Table 3.

\section{Results and discussion}

Applying Eq. 1 for calculating $\mathrm{ChF}^{\mathrm{Hg}}$ and using USEtox for the related steady-state mass of $\mathrm{Hg}$ in the different environmental compartments per RF district gave the results shown in Table 4, indicating that the maximum 


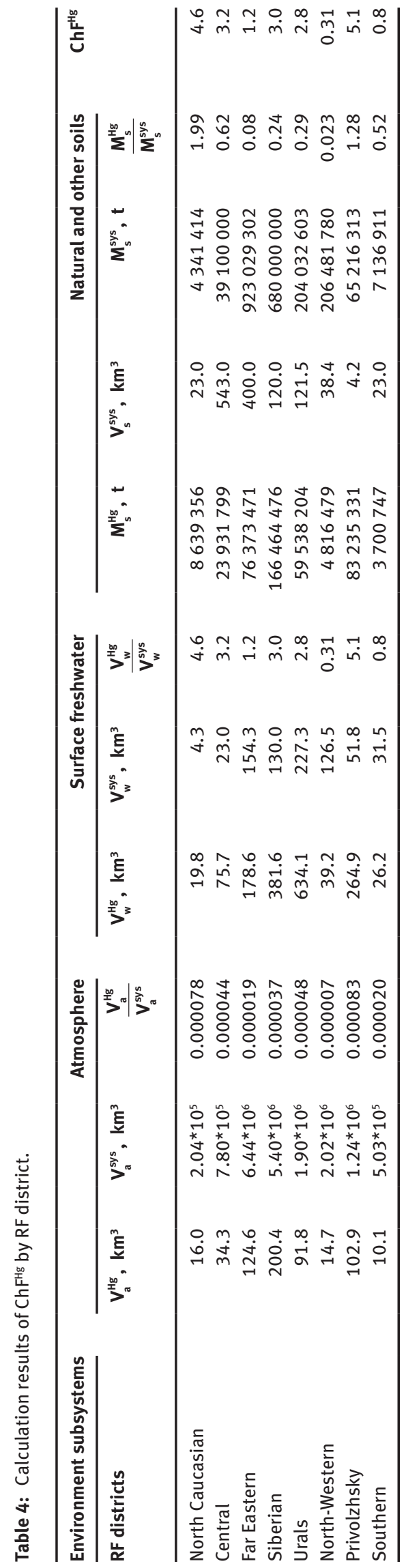




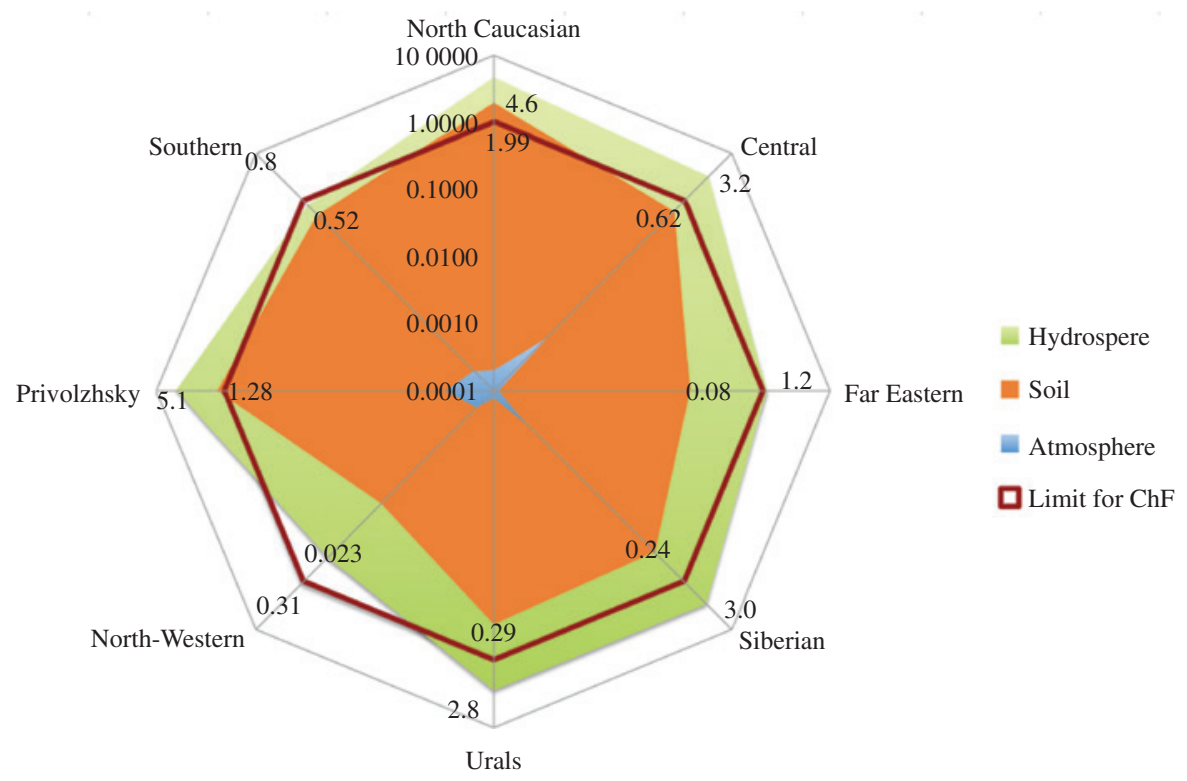

Fig. 2: Radar chart showing estimated environmental impacts of mercury and its compounds in RF districts, calculated using ChF methodology.

environmental impact derives from mercury and its compounds that enter aqueous bodies in the course of human activities. The impacts of mercury and its compounds, obtained using the ChF estimation methodology, are presented as a radar chart in Fig. 2.

A more detailed estimate for the individual regions in the districts is presented in Fig. 3.

$\mathrm{RF}$ regions where the value of $\mathrm{ChF}^{\mathrm{Hg}}$ is close to or $>1$ include:

- the Republic of Bashkortostan and the Orenburg Region in the Privolzhsky district;

- the Republic of North Ossetia-Alania North Caucasian district;

- the Amur Region in the Far Eastern district;

- the Sverdlovsk Region and the Chelyabinsk Region in the Urals district;

- the Oryol Region in the Central district; and

- the Transbaikal Region, the Krasnoyarsk Region and the Irkutsk Region in the Siberian district.

These regions are hence estimated to likely lack the required ecological space (water resources and soil) for dilution of mercury pollution to levels below the assigned limiting conditions, thereby making it necessary to reduce emissions of mercury and its compounds to the environment (primarily to surface freshwater bodies).

To evaluate the results, the calculated impact levels in RF regions were compared with experimental data for mercury concentrations in environmental subsystems collected from various sources. For uniform presentation of data, experimental values were compared to MAC values [21-23]. Figure 4 presents data obtained for various regions of Russia, showing whether measured mercury concentrations exceed the MAC for fishery objects [22].

Our systems analysis shows good agreement between estimated ChFHg (Fig. 3) and experimental data on MAC overrun (Fig. 4), particularly for freshwater bodies. In regions in which the chemical footprint is estimated to be $>1$, some territories have water bodies where mercury content exceeds the MAC several-fold. However, although the calculated $\mathrm{ChF}^{\mathrm{Hg}}$ in other districts (North-Western and Southern) was $<1$, measurements still show that the MAC is exceeded in some regions (the Leningrad Region and the Volgograd Region) and other sub-regions of these districts.

The discrepancies between calculated and actual data may be related to the following:

1. Imperfect and incomplete data used for validating the model. In some cases, actual mercury content was estimated from point measurements, which may introduce errors when extrapolated to an entire $\mathrm{RF}$ district/region; 


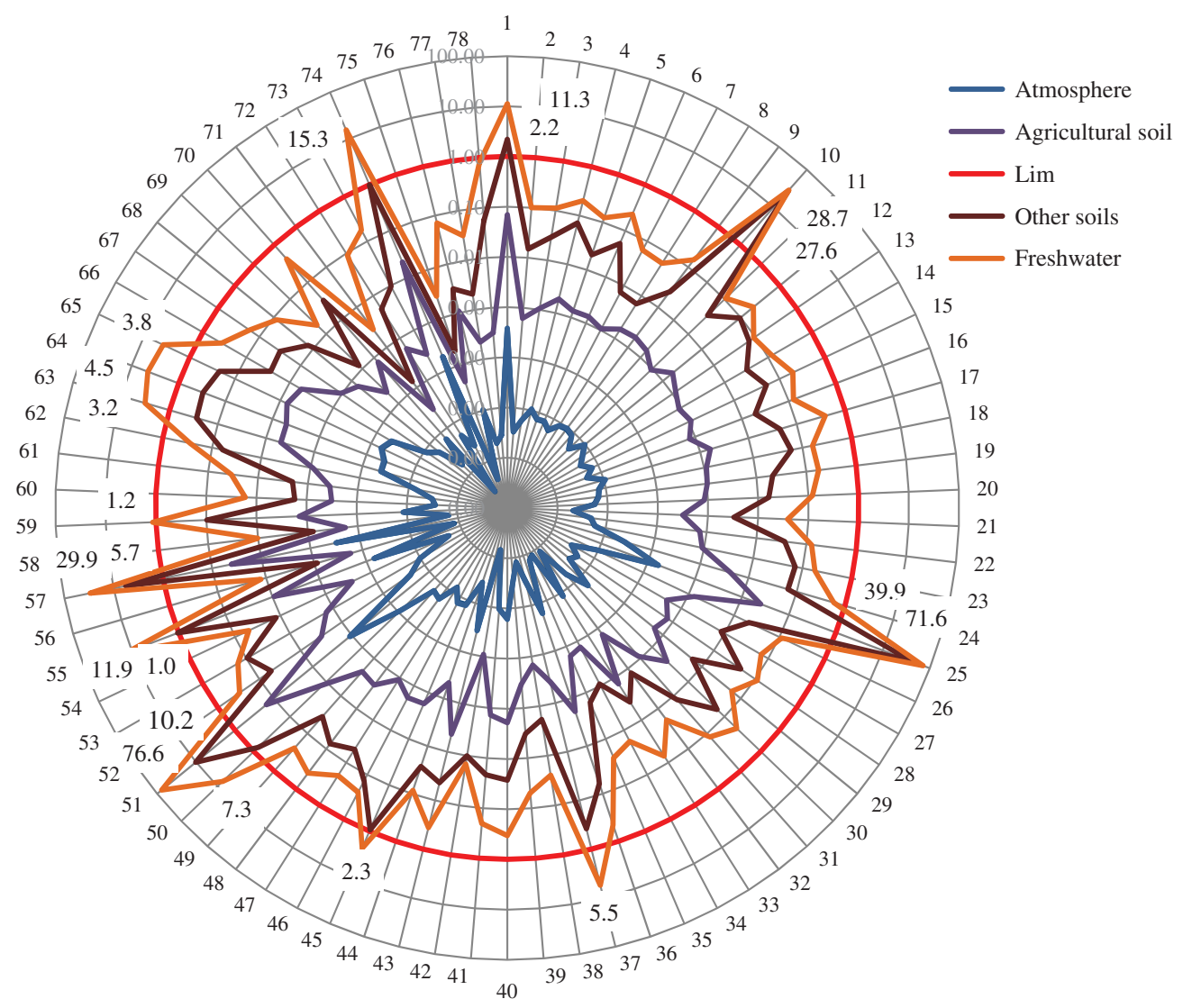

\begin{tabular}{|l|l|l|l|l|l|}
\hline 1 & Republic of Bashkortostan & 27 & Smolensk Region & 53 & Stavropol Region \\
\hline 2 & Republic of Mari El & 28 & Tambov Region & 54 & Kurgan Region \\
\hline 3 & Republic of Mordovia & 29 & Tver Region & 55 & Sverdlovsk Region \\
\hline 4 & Republic of Tatarstan & 30 & Tula Region & 56 & Tyumen Region including autonomous areas \\
\hline 5 & Republic Udmurt & 31 & Yaroslavl Region & 57 & Chelyabinsk Region \\
\hline 6 & Republic of Chuvash & 32 & Republic of Karelia & 58 & Republic of Altai \\
\hline 7 & Perm Region & 33 & Republic of Komi & 59 & Republic of Buryatia \\
\hline 8 & Kirov Region & 34 & Arhangelsk Region & 60 & Republic of Tyva \\
\hline 9 & Nizhny Novgorod Region & 35 & Vologda Region & 61 & Republic of Khakassia \\
\hline 10 & Orenburg Region & 36 & Kaliningrad Region & 62 & Altai Region \\
\hline 11 & Penza Region & 37 & Leningrad Region & 63 & Transbaikal Region \\
\hline 12 & Samara Region & 38 & Murmansk Region & 64 & Krasnoyarsk Region \\
\hline 13 & Saratov Region & 39 & Novgorod Region & 65 & Irkutsk Region \\
\hline 14 & Ulyanovsk Region & 40 & Pskov Region & 66 & Kemerovo Region \\
\hline 15 & Belgorod Region & 41 & Republic of Adygea & 67 & Novosibirsk Region \\
\hline 16 & Bryansk Region & 42 & Republic of Kalmykia & 68 & Omsk Region \\
\hline 17 & Vladimir Region & 43 & Krasnodar Region & 69 & Tomsk Region \\
\hline 18 & Voronezh Region & 44 & Astrakhan Region & 70 & Republic of Sakha (Yakutia) \\
\hline 19 & Ivanovo Region & 45 & Volgograd Region & 71 & Kamchatka Krai \\
\hline 20 & Kaluga Region & 46 & Rostov Region & 72 & Primorsky Krai \\
\hline 21 & Kostroma Region & 47 & Republic of Dagestan & 73 & Khabarovsk Region \\
\hline 22 & Kursk Region & 48 & Republic of Ingushetia & 74 & Amur Region \\
\hline 23 & Lipetsk Region & 49 & Republic of Kabardino-Balkaria & 75 & Magadan Region \\
\hline 24 & Moscow Region & 50 & Republic of Karachay-Cherkess & 76 & Sakhalin Oblast \\
\hline 25 & Oryol Region & 51 & Republic of North Ossetia-Alania & 77 & Jewish Autonomous Region \\
\hline 26 & Ryazan Region & 52 & Republic of Chechen & 78 & Chukotka Autonomous District \\
\hline
\end{tabular}

Fig. 3: Radar chart showing estimated environmental impacts of mercury and its compounds in RF regions, calculated using ChF methodology

2. Calculations by RF districts and regions give rough approximations due to the large areas involved; the size of territories being assessed should therefore be decreased in future work to obtain more precise data for the respective regions; 


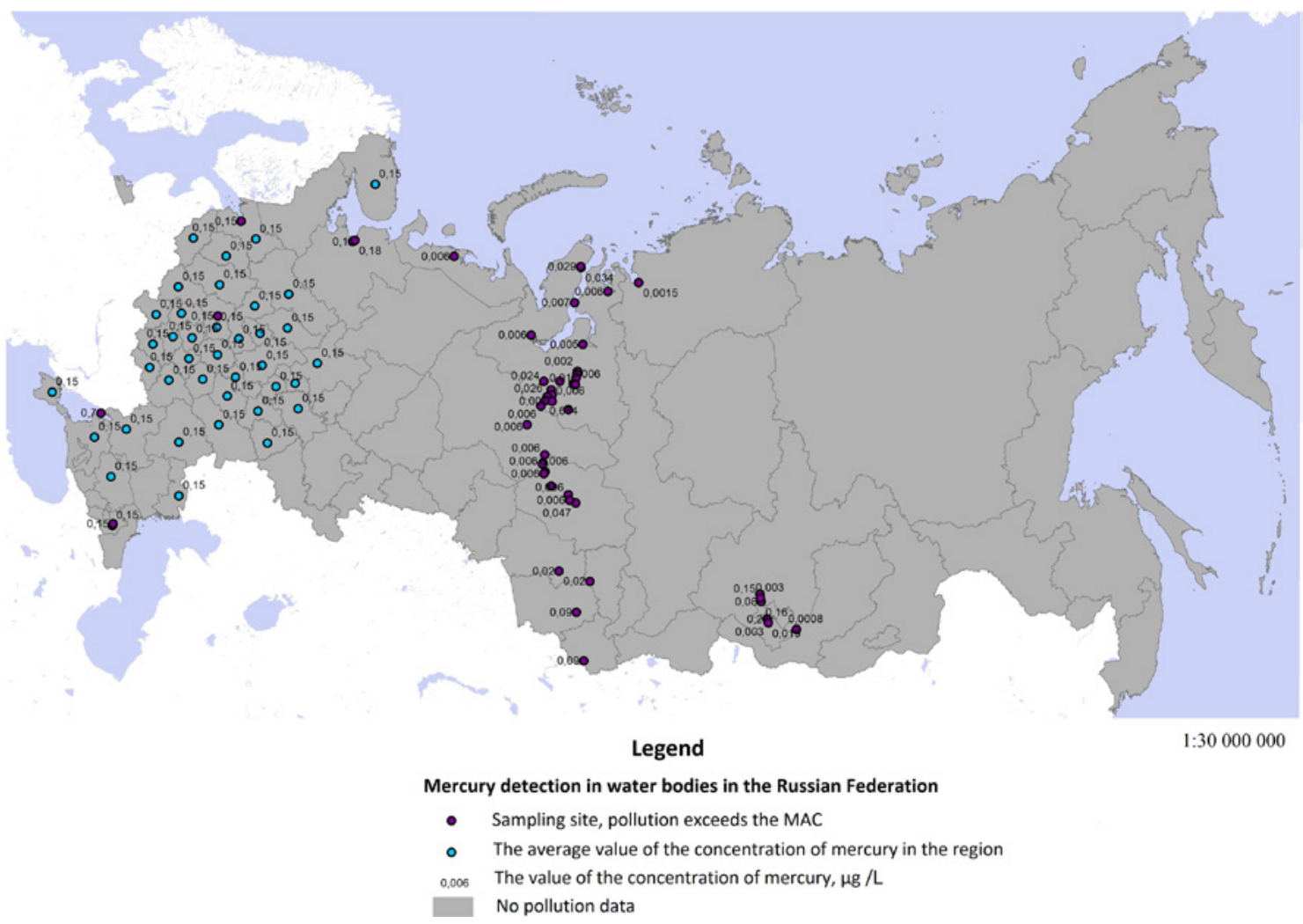

Fig. 4: Comparison of results with MAC values for fishery water bodies in Russian regions.

3. Natural soil in USEtox was used as an emission compartment for releases into soil, whereas it is usually industrial soils that are subject to mercury inputs from various industrial processes. However, industrial soils were not implemented as a separate emission compartment in the model, but could in future be considered separately, with their own specific characteristics;

4. The model did not account for cumulative damage from emissions of previous years, which in some regions (especially where chloro-alkaline plants formerly existed) may also result in considerable errors. Examples include significant mercury contamination in the Irkutsk Region due to the mercury method of chlorine production at Sayanskkhimplast and Usol'ekhimprom. Subsequent calculations might consider including cumulative damage as an additional source of anthropogenic contamination.

\section{Conclusion}

Russia considers the Minamata Convention on Mercury as one of the key global environmental protection treaties developed under UNEP during the past decade [33]. Pursuant to Decree no. 1242-r "On Signing the Minamata Convention on Mercury", Russia signed the Convention at the $69^{\text {th }}$ session of the UN General Assembly. Russia's interest in this Convention derives from the understanding that mercury contamination has dangerous ecological consequences, not only on a local, but also on a regional scale [32]. In Russia, mercury is released to all relevant environmental compartments including air, surface water and soil, largely through different industrial activities. Our results estimating the chemical footprint of mercury in different districts and regions of the Russian Federation (i.e. the environmental capacity in each region to dilute mercury releases to below levels that can lead to adverse effects on humans and ecosystems) emphasizes that most districts have sufficiently large environments, while some districts, most notably the Privolzhsky and North Caucasian districts, do not have sufficient water and soil resources to dilute the mercury released into 
these systems to safe levels. This has important implications for these regions, as mercury contamination threatens their ecosystems and life-supporting environment to an extent that might lead to long-term and irreversible damage, while having enormous economic implications in cases where remediation of contaminated water and soil bodies is required. It is also important to note that pressure from mercury releases into the environment in these rather large districts is not equally distributed over the entire studied areas, but is rather a local phenomenon, with large amounts of mercury released to water and soil close to industrial sites. These are the areas of highest concern, a conclusion also supported by measured mercury water and soil concentrations used to evaluate modeled results. To more accurately identify and assess these rather local phenomena, our chemical footprint method will in future have to be combined with more precise, spatially disaggregated data.

The chemical footprints of mercury and its compounds, estimated using the methodology described, were presented to the Ministry of the Natural Resources and Environment of the Russian Federation. It is planned to use these district-specific results as one of the criteria for prioritizing action on sources of environmental mercury contamination when designing Russia's national action plans for ratifying the Minamata Convention.

Acknowledgements: This research was supported by the Russian Science Foundation (grant 18-17-00219) and by the Marie Curie project Quan-Tox (grant agreement no. 631910), funded by the European Commission under the Seventh Framework Programme.

\section{References}

[1] C. N. Waters, J. Zalasiewicz, C. Summerhayes, A. D. Barnosky, C. Poirier, A. Gałuszka, A. Cearreta, M. Edgeworth, E. C. Ellis, M. Ellis, C. Jeandel, R. Leinfelder, J. R. McNeill, D. B. Richter, W. Steffen, J. Syvitski, D. Vidas, M. Wagreich, M. Williams, A. Zhisheng, J. Grinevald, E. Odada, N. Oreskes, A. P. Wolfe. Science 351, 137 (2016).

[2] D. H. Meadows, J. Randers, D. L. Meadows. Limits to Growth: The 30-Year Update, 368 p, Chelsea Green Publishing Company, White River Junction, Vt (2004).

[3] J. Rockström, W. Steffen, K. Noone, A. Persson, F. S. Chapin, E. F. Lambin, T. M. Lenton, M. Scheffer, C. Folke, H. J. Schellnhuber, B. Nykvist, C. A. de Wit, T. Hughes, S. van der Leeuw, H. Rodhe, S. Sorlin, P. K. Snyder, R. Costanza, U. Svedin, M. Falkenmark, L. Karlberg, R. W. Corell, V. J. Fabry, J. Hansen, B. Walker, D. Liverman, K. Richardson, P. Crutzen, J. A. Foley. Ecol. Soc. 14, 32 (2009).

[4] J. Rockström, W. Steffen, K. Noone, A. Persson, F. S. Chapin, E. F. Lambin, T. M. Lenton, M. Scheffer, C. Folke, H. J. Schellnhuber, B. Nykvist, C. A. de Wit, T. Hughes, S. van der Leeuw, H. Rodhe, S. Sorlin, P. K. Snyder, R. Costanza, U. Svedin, M. Falkenmark, L. Karlberg, R. W. Corell, V. J. Fabry, J. Hansen, B. Walker, D. Liverman, K. Richardson, P. Crutzen, J. A. Foley. Nature 461, 472 (2009).

[5] W. Steffen, K. Richardson, J. Rockström, S. E. Cornell, I. Fetzer, E. M. Bennett, R. Biggs, S. R. Carpenter, W. de Vries, C. A. de Wit, C. Folke, D. Gerten, J. Heinke, G. M. Mace, L. M. Persson, V. Ramanathan, B. Reyers, S. Sörlin. Science 347, 1259855 (2015).

[6] M. MacLeod, M. Breitholtz, I. T. Cousins, C. A. de Wit, L. M. Persson, C. Rudén, M. S. McLachlan. Environ. Sci. Technol. 48, 11057 (2014).

[7] K. Fang, R. Heijungs, G. R. DeSnooa. Ecol. Econ. 114, 218 (2015).

[8] L. Čuček, P. S. Varbanova, J. J. Klemes, Z. J. Kravanja. Chem. Eng. Trans. 29, 61 (2012).

[9] M. Wackernagel, W. E. Rees. Our Ecological Footprint: Reducing Human Impact on the Earth, 160 p, New Society Publishers, Philadelphia (PA), USA (1996).

[10] L. Čuček, J. J. Klemes, Z. J. Kravanja. J. Clean. Prod. 34, 9 (2012).

[11] J. Panko, K. Hitchcock. EM Mag. 12, 12 (2011).

[12] Clean Production Action. Chemical Footprint. Available from: http://www.chemicalfootprint.org/learn. Accessed: 29 March 2018.

[13] P. Fantke, R. Weber, M. Scheringer. Sustain. Chem. Pharm. 1, 1 (2015).

[14] A. Bjørn, M. Diamond, B. Birkved, M. Z. Hauschild. Environ. Sci. Technol. 48, 13253 (2014).

[15] S. Liang, Y. Wang, S. Cinnirella, N. Pirrone. Environ. Sci. Technol. 49, 3566 (2015).

[16] World Health Organization. Mercury and health. Fact sheet \# 361 January 2016. Available from: http://www.who.int/mediacentre/factsheets/fs361/en/ (2016). 
[17] J. Weinberg. NGO Introduction to Mercury Pollution. IPEN web. Available from: http://www.ipen.org/documents/ngo-introduction-mercury-pollution (2010).

[18] Russian Federation. Decree of the Government of the Russian Federation as of July 7, 2014, no. 1242-r "On signing the Minamata Convention on Mercury" (2014).

[19] S. V. Gavrish. J. Appl. Mech. Tech. Phys. 52, 924 (2011).

[20] R. J. K. Helmes, M. A. J. Huijbregts, A. D. Henderson, O. Jolliet. Int. J. Life Cycle Assess. 17, 646 (2012).

[21] Russian Federation. Maximum allowable concentrations (MAC) of pollutants in the atmospheric air of populated areas: Health standards. Moscow. GN 2.1.6.1338-03 (2003).

[22] Federal Fisheries Agency. Order of the Federal Fisheries Agency no. 20 as of January 18, 2010 on the approval of the standards of water quality in water bodies of commercial fishing importance, including the standards of maximum allowable concentrations of hazardous compounds in the waters of the water bodies of commercial fishing importance. Moscow (2010).

[23] Russian Federation. Maximum allowable concentrations (MAC) of chemical compounds in soil: Health standards. Moscow. GN 2.1.7.2041-06 (2006). ISBN 5-7508-0599-0599.

[24] International Organization for Standardization. Environmental management - Life cycle assessment - Principles and framework. ISO 14040:2006 (2006).

[25] R. K. Rosenbaum, M. D. Margni, O. Jolliet. Environ. Int. 33, 624 (2007).

[26] M. MacLeod, M. Scheringer, T. E. McKone, K. Hungerbuhler. Environ. Sci. Technol. 44, 8360 (2010).

[27] D. W. Pennington, A. Margni, C. Amman, 0 Jolliet. Environ. Sci. Technol. 39, 1119 (2005).

[28] R. K. Rosenbaum, T. M. Bachmann, L. S. Gold, M. A. J. Huijbregts, O. Jolliet, R. Juraske, A. Koehler, H. F. Larsen, M. MacLeod, M. D. Margni, T. E. McKone, J. Payet, M. Schuhmacher, D. van de Meent, M. Z. Hauschild. Int. J. Life Cycle Assess. 13, 532 (2008).

[29] T. B. Westh, M. Z. Hauschild, M. Birkved, M. S. Jørgensen, R. K. Rosenbaum, P. Fantke. Int. J. Life Cycle Assess. 20, 299 (2015).

[30] R. Kumari. Atmos. Pollut. Res. 2, 513 (2011).

[31] Ministry of Natural Resources and Ecology of the Russian Federation. Public report on the state and use of Russian Federation mineral resources in 2012. Moscow (2013).

[32] United National Environmental Programme. Toolkit for Identification and Quantification of Mercury Releases. Available from: http://www.unep.org/chemicalsandwaste/what-we-do/technology-and-metals/mercury/toolkit-identification-andquantification-mercury-releases. Accessed: 12 Nov 2017.

[33] United Nations, 69th session of General assembly. Speech of Deputy Minister of natural resources and ecology of the Russian Federation R.R. Gizatulin at the Minamata Convention on Mercury signing ceremony. October 25, 2014. Seat of the United Nations, New York (2014).

[34] Ministry of Natural Resources and Ecology of the Russian Federation. Public report on the state and use of Russian Federation water resources in 2014. Moscow (2015). 